\title{
Konversi Faktor Penerimaan Audit Teknologi oleh Kantor Akuntan Publik di Indonesia Menggunakan Kerangka Kerja I-TOE
}

\author{
Lia Dama Yanti' ${ }^{1}$, Yunia Oktari² \\ Universitas Buddhi Dharma \\ lia@buddhidharma.ac.id
}

\begin{abstract}
Abstrak
Banyak bisnis sekarang beralih ke e-bisnis dan menerapkan sistem informasi akuntansi terkomputerisasi. Fenomena ini telah berdampak pada profesi audit TI, audit laporan keuangan dan penelusuran dokumen sumber elektronik. Computer Assited Auditing Techniques and Tools (CAATTs) adalah teknologi audit yang memungkinkan audit TI dilakukan secara efisien, efektif, dan mengurangi waktu audit. Namun, sedikit yang diketahui tentang adopsi CAATTs oleh kantor akuntan publik. Makalah ini menyajikan paradigma baru Individual-Technology Organization Environment (I-TOE) untuk menyelidiki penerimaan CAATTs di kantor akuntan publik. Ada celah yang ada di literatur sebelumnya yang diterima dari hanya auditor individu. Pandangan dan tidak membahas masalah baik dari perspektif organisasi maupun individu. Akibatnya, makalah ini memberikan kontribusi untuk memperluas literatur dengan memberikan pemahaman yang lebih baik tentang hubungan antara organisasi dan faktor individu dalam meramalkan adopsi dan investasi. Kombinasi Teori Mempersatukan Penerimaan dan Penggunaan Teknologi (UTAUT= Unified Theory of Acceptance and Use of Technology), dan kerangka Organisasi-Lingkungan Teknologi (TOE=Technology Organization Environment) digunakan sebagai teori yang mendasarinya. Selain ini, tulisan ini sesuai dengan variabel-variabel baru dari risiko teknologi, kecocokan tugas teknologi, kesiapan organisasi dan komitmen manajemen puncak. Kerangka ITOE berkontribusi pada kantor akuntan publik profesional yang perlu mengukur penerimaan untuk kemajuan profesi audit. Studi eksperimental di masa depan dapat dilakukan untuk memberikan bukti dan secara empiris memvalidasi kerangka I-TOE pada area lainnya.
\end{abstract}

Kata kunci: Audit, Penerapan, Teknologi, TOE, Akuntan Publik

\section{Pendahuluan}

CAATTs adalah alat dan teknik audit komputer yang digunakan untuk membantu penyelesaian audit eksternal dan internal atas laporan keuangan organisasi dan kendali internal. CAATTs mencakup penggunaan teknologi apa pun dalam audit, misalnya, kertas kerja elektronik, aplikasi pengolah kata, aplikasi spreadsheet, perangkat lunak analisis statistik dan program aplikasi komputer (Braun, 2003). CAATTs diklasifikasikan ke dalam lima kategori: data uji, fasilitas uji terintegrasi, paralel simulasi, modul audit tersemat dan perangkat lunak audit umum (Braun, 2003). CAATTs terdiri dari alat dan teknik otomatis yang membantu auditor untuk mengutip, memeriksa dan mengevaluasi logika data audit yang diproses. Dengan CAATTs, auditor juga bisa menganalisis data yang diekstrak dan memeriksa silang data langsung dalam berbagai basis data dan perangkat lunak aplikasi (Debreceny, 2005).

Tingkat implementasi CAATTs masih minim dan tidak dimanfaatkan secara luas oleh Kantor Akuntan Publik (Curtis, 2008). Perusahaan besar memiliki kemungkinan lebih besar untuk

${ }^{1}$ Korespondensi: Lia Dama Yanti. Universitas Buddhi Dharma. Jl. Imam Bonjol No. 41 Karawaci Ilir, Tangerang. lia@buddhidharma.ac.id

${ }^{2}$ Korespondensi: Yunia Oktari. Universitas Buddhi Dharma. Jl. Imam Bonjol No. 41 Karawaci Ilir, Tangerang. yunia.oktari@buddhidharma.ac.id 
menerapkan CAATTs. Namun, Kantor Akuntan Publik kecil hingga menengah masih berjuang dalam adopsi CAATTs. Penyusunan Modal ketat (anggaran) adalah faktor yang memungkinkan untuk adopsi CAATTs yang rendah (Curtis, 2008). Oleh karena itu, keputusan Kantor Akuntan Publik atas adopsi CAATTs harus didasarkan pada aspek teknologi, yang sesuai dengan kemampuan organisasi dan tuntutan lingkungan yang berubah. Dari literatur sebelumnya, peneliti telah menemukan bahwa ada kesenjangan dalam adopsi CAATTs, di mana itu tidak cukup memadai untuk mempelajari penerimaan CAATTs dari perspektif individu atau perspektif organisasi secara terpisah. Ini karena niat untuk mengadopsi CAATTs oleh Kantor Akuntan Publik dapat dipengaruhi oleh auditor individu di perusahaan. Sebagai contoh, jika auditor merasa bahwa menggunakan teknologi CAATTs dalam pekerjaan audit akan bermanfaat dan meningkatkan kinerja pekerjaan mereka, maka mereka akan mengusulkan kepada perusahaan untuk mengadopsi CAATTs.

Selain itu, niat auditor individu untuk mengadopsi CAATTs mungkin juga dipengaruhi oleh kebijakan perusahaan audit. Misalnya, dukungan dari manajemen puncak atau penggunaan wajib dari CAATTs yang dikenakan oleh perusahaan audit. Sementara banyak penelitian sebelumnya menyelidiki perilaku adopsi niat CAATTs hanya dari perspektif individu, makalah ini menyajikan adopsi CAATTs dari sudut pandang individu dan organisasi. Penting untuk menyelidiki faktor kontribusi individu dan organisasi dari perilaku yang disengaja perusahaan audit karena lebih komprehensif. Selain itu, sumber daya manusia juga penting untuk dipertimbangkan dalam evaluasi perusahaan audit karena organisasi dijalankan oleh tenaga kerja individu dan itu adalah penting untuk mengevaluasi penerimaan mereka terhadap TI (Venkatesh, 2003).

Menyadari masalah dan kesenjangan dalam literatur yang ada, makalah ini bertujuan untuk mengembangkan kerangka kerja CAATTs yang komprehensif dengan paradigma baru yang mengintegrasikan semua faktor Individual (I), Technology (T), Organization (O), dan Environment (E), disebut sebagai I-TOE, dan untuk mengatasi sudut pandang individu dan organisasi.

Makalah ini memberikan kontribusi untuk praktik profesi audit dengan analisis komprehensif organisasi CAATTs mengadopsi faktor-faktor seperti faktor adopsi individu, kesiapan organisasi, komitmen manajemen puncak, risiko teknologi dan fit tugas. Penelitian ini akan membantu perusahaan audit untuk membangun dan menerapkan strategi organisasi untuk meningkatkan penerimaan CAATT dan mengurangi risikonya. Studi ini juga berkontribusi pada literatur adopsi teknologi yang ada dengan pengembangan paradigma inklusif baru I-TOE yang mengintegrasikan kerangka UTAUT dan TOE dalam mempelajari adopsi CAATTs.

\section{Literature Review/Related Works \\ UTAUT}

UTAUT adalah model yang berguna dalam mengevaluasi keberhasilan penerimaan Teknologi Informasi/Sistem Informasi yang baru diperkenalkan. UTAUT juga membantu manajer perusahaan untuk memahami teknologi baru dari faktor penerimaan sehingga mereka dapat mengembangkan strategi perbaikan lebih lanjut untuk karyawan mereka.

(Venkatesh, 2003) mengembangkan model kohesif dari UTAUT yang menggabungkan konstruksi dari Theory of Reasoned Action (TRA), Technology of Acceptance Model (TAM), Model Motivasi, Theory of Plan Behaviour, Teori Difusi Inovasi dan Teori Kognitif Sosial. (Venkatesh, 2003) menemukan bahwa harapan kinerja, harapan usaha, pengaruh sosial dan kondisi fasilitasi terkait langsung dengan niat perilaku untuk menggunakan teknologi yang akibatnya mempengaruhi pengguna keputusan untuk mengadopsi teknologi. Niat untuk menggunakan teknologi berasal dari konsep yang dimodifikasi dalam Technology of Acceptance Model. Selanjutnya, niat untuk menggunakan sistem akan menjelaskan sistem aktual pengguna 
pemakaian. Niat ini telah ditemukan menjadi faktor pendorong menuju aktual individu perilaku seperti yang dibahas dalam Theory of Reasoned Action (Taylor, 1995). Dengan kriteria efek jenis kelamin, usia, pengalaman dan kesukarelaan penggunaan.

\section{Kerangka Kerja TOE}

Ada aspek lain yang perlu dipertimbangkan perusahaan selain melihat individu faktor karyawan. Lingkungan teknologi, organisasi, dan eksternal perusahaan merupakan faktor penting yang dapat memengaruhi keputusan investasi CAATTs. Kerangka kerja TOE (Tornatzky, 1990) membahas aspek-aspek mendasar ini.

Konteks teknologi mengacu pada karakteristik teknologi dan ketersediaan untuk perusahaan. Di kasus adopsi CAATTs, Kantor Akuntan Publik harus benar-benar mengetahui karakteristik CAATTs seperti manfaat biaya dan risiko teknologi sebelum diadopsi. Namun demikian, keputusan apakah atau tidak untuk menggunakan CAATTs ditentukan tidak hanya oleh persepsi perusahaan dari karakteristik teknologi, tetapi juga apakah teknologi sesuai dengan tugas audit yang perlu dilakukan. Seperti yang disarankan oleh (DeLone, 2003), "Para peneliti juga harus mempertimbangkan sifat, tingkat, kualitas dan kepatutan penggunaan sistem". Meskipun teknologi dapat dianggap berguna dan canggih, jika tidak sesuai dengan persyaratan tugas audit, organisasi mungkin tidak mengadopsi teknologi tersebut.

Untuk adopsi CAATTs, harus sesuai dengan tugas-tugas yang dilakukan oleh perusahaan audit. (Curtis, 2008).

\section{Metode Penelitian/Method}

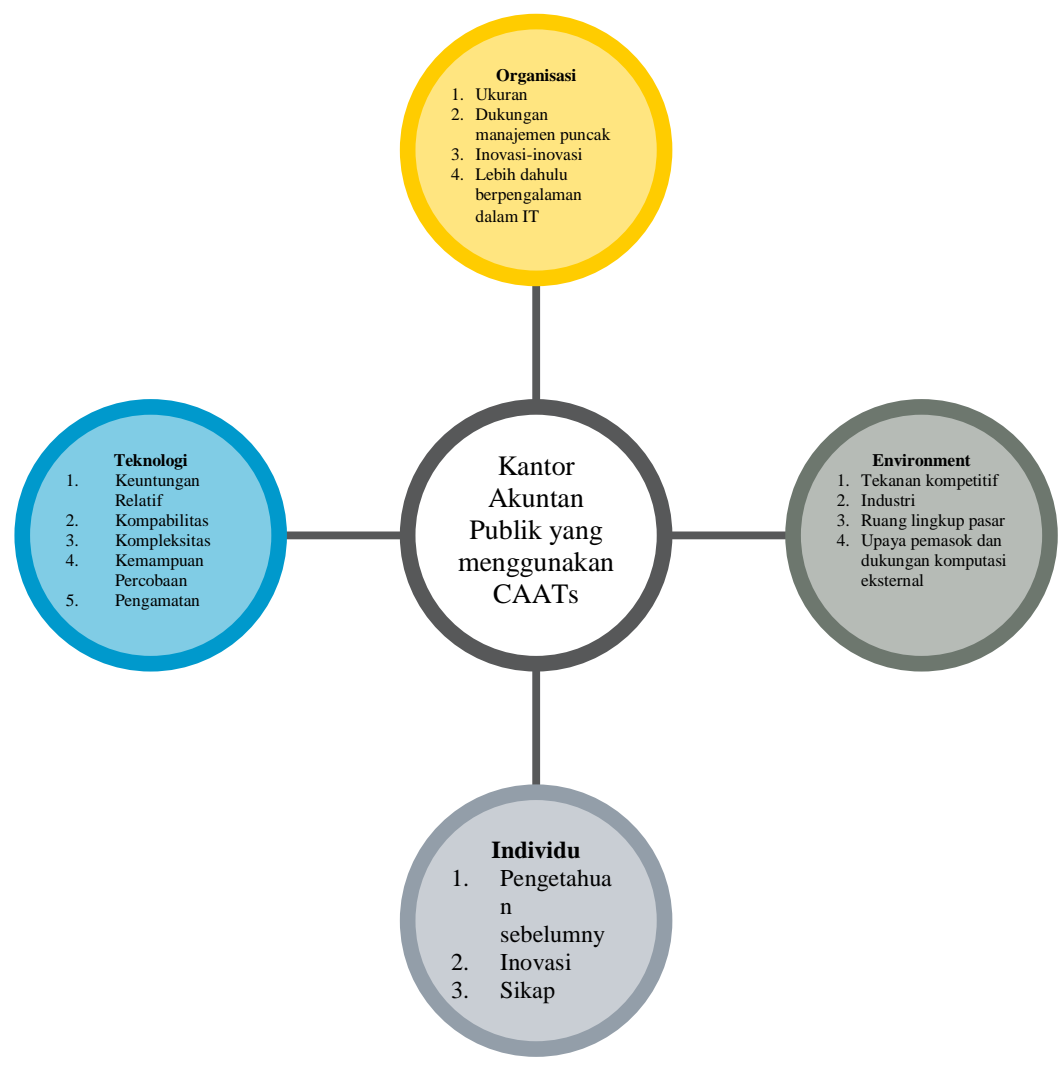

Gambar 1. Konsep Pendekatan I-TOE

\section{Konteks Teknologi dan atributnya.}

1. Keuntungan relatif, indikator utama inovasi TI dan mengacu pada "sejauh mana suatu inovasi dianggap lebih baik dari ide sebelumnya 
2. Kompabilitas, sejauh mana suatu inovasi dirasakan konsisten dengan nilai yang berjalan, pengalaman masa lalu dan kebutuhan pontensial

3. Kompleksitas, sejauh mana suatu inovasi dianggap relative sulit dipahami dan digunakan

4. Kemampuan percobaan, mengukur sejauh mana suatu inovasi dapat diuji cobakan secara terbatas

5. Pengamatan, sejauh mana hasil menggunakan suatu inovasi ternyata tidak aman

\section{Konteks Organisasi.}

1. Ukuran, lebih kearah skala ukuran perusahaan

2. Dukungan manajemen puncak, mencurahkan waktu untuk mendukung TI secara proposional terkait biaya dan potensi, meninjau rencana, menindaklanjuti hasil serta memfasilitasi permasalahan manajemen yang terlibat dengan mengintegrasikan TI dengan proses bisnis

3. Inovasi-inovasi, sejauh mana seorang anggota mengadopsi suatu inovasi lebih dahulu dari anggota lainnya dari konteks sosial yang sama

4. Lebih dahulu berpengalaman dalam TI, tingkat pengalaman pengguna dengan teknologi serupa sebelumnya.

\section{Konteks Environment}

1. Tekanan kompetitif, tingkat tekanan yang dirasakan oleh perusahaan dari pesaing dalam industri

2. Industri, sektor yang menjadi tempat bisnisnya

3. Ruang lingkup pasar, luas horizontal opersional perusahaan

4. Upaya pemasok dan dukungan komptasi external, mempengaruhi probabilitas bahwa suatu inovasi akan diadopsinya

\section{Hasil}

Kerangka kerja I-TOE memberikan pandangan yang lebih komprehensif tentang adopsi CAATTs. Pengambil keputusan dapat mengevaluasi penerimaan teknologi audit baru pada organisasi mereka dari setiap aspek individu, teknologi, organisasi dan eksternal lingkungan hidup. Dapat dipahami bahwa dengan mempertimbangkan hanya satu dimensi penerimaan tidak dapat memberikan penilaian yang memadai tentang adopsi teknologi. Sifat sosial dalam adopsi teknologi di antara perusahaan menyimpulkan bahwa menggunakan teori berbasis individu tidak pantas (Parker, 2007). Pemilik, Manajer dan Supervisor adalah individu dalam perusahaan yang mempengaruhi keputusan adopsi tetapi perusahaan juga dipengaruhi oleh lingkungan sosial mereka. Tergantung pada hanya satu teori baik UTAUT atau I-TOE yang dapat membatasi persepsi adopsi CAATTs. Dengan demikian, para pengambil keputusan dalam organisasi hanya dapat mengevaluasi keputusan investasi CAATTs dari perspektif terbatas. Karena alasan itu, kerangka kerja adopsi I-TOE mengintegrasikan harapan kinerja individu, harapan usaha, pengaruh sosial, memfasilitasi kondisi, dan motivasi hedonis.

Konstruksi dari UTAUT dan teknologi, organisasi dan konstruksi lingkungan dari TOE untuk melengkapi masing-masing sudut pandang individu dan organisasi. Masa depan penelitian dapat dilakukan untuk memberikan bukti empiris dan memvalidasi kerangka I-TOE. Selain itu, hubungan antara konstruk juga dapat diselidiki lebih lanjut.

\section{Simpulan}

Tulisan ini memiliki tujuan untuk mengembangkan paradigma I-TOE yang memberikan kontribusi komprehensif konteks individu, teknologi, organisasi dan lingkungan untuk diperiksa. 
Pengadopsian CAATTs di kantor akuntan publik. Dikatakan bahwa penerimaan CAATTs tidak hanya tergantung pada penerimaan auditor individu tetapi juga bergantung pada manajemen organisasi, karakteristik teknologi dan faktor lingkungan lainnya. Kompleksitas AIS klien, kesiapan perusahaan audit, komitmen manajemen puncak, teknologi biaya dan manfaat, tanggung dan tugas-fit untuk membahas masalah CAATTs dari kesalahan visi organisasi. Karya ilmiah ini mengadaptasi kerangka UTAUT dan TOE sebagai teori fundamental. Kerangka kerja I-TOE akan menguntungkan perusahaan-perusahaan audit publik dengan para pendahulu yang mereka perlu disengaja dalam pengadopsian CAATTs dan untuk memprediksi penerimaan CAATTs dalam organisasi mereka.

\section{Daftar Pustaka}

Braun, R. L. (2003). Computer Assisted Audit Tools and Techniques:Analysis and Perspectives. Managerial Auditing Journal, 725-731.

Curtis, M. B. (2008). An Examination of Contextual Factors and Individual Characteristics Affecting Technology Implementation Decisions in Auditing. International Journal of Accounting Information Systems, 104-121.

Debreceny, R. L. (2005). Employing Generalized Audit Software in the Financial Services Sector:Challenges and Opportunities. Managerial Auditing Journal, 605-618.

DeLone, W. H. (2003). The DeLone and McLean Model of Information Systems Success: A TenYear Update. Journal, 9-30.

Parker, C. M. (2007). New Directions for Research on SME-eBusiness: Insights from an Analysis of Journal Articles from 2003 to 2006. Journal of Information, 21-40.

Taylor, S. \&. (1995). Understanding Information Technology. Information Systems Research, 144-176.

Tornatzky, L. G. (1990). The Processes of Technological. Lexington, MA: Lexington Books.

Venkatesh, V. M. (2003). User Acceptance of Information Technology: Toward a Unified. MIS Quarterly, 425-478. 